\title{
"The Leather Industry Development in Tanggulangin in Facing Asean Economic Community (AEC) 2015 with Quantitative Strategic Planning Matrix (QSPM)"
}

\author{
by: \\ Bambang Purwoko \\ Economic Department University of W.R. Supratman, Surabaya-Indonesia \\ Ahmad Gamal \\ Economic Department University of W.R. Supratman, Surabaya-Indonesia \\ Dedy Kunhadi \\ Engineering Department University of W.R. Supratman, Surabaya-Indonesia
}

\begin{abstract}
In facing the Asean Economic Community (AEC) 2015, the challenge that is being faced by Indonesian citizens of using the ASEAN market, the competitiveness is still relatively low compared other ASEANs, especially Singapore, Malaysia, and Thailand.

The problem that was faced by grand entrepreneurs which incorporated in INTAKO cooperative in facing competitiveness are qualified products, SNI certificated and primary services. Then leather crafts industry in Tanggulangin, Sidoarjo needs a development strategy so that leather crafts industry in Tanggulangin could not cease to exist and is prepared to face the competitiveness.

The purpose of this research is to know the leather crafts industry's development work model which incorporated in INTAKO cooperative in facing ASEAN market especially MEA 2015's enforcement. This development strategy is capable to compete with other/similar products from ASEAN nations. We wish that the choosing of this strategy model is capable to elevate quality products using skilled human resources, fueled raw material supplies, supporting modernized media and tools, product innovation, primary service and integrated promotion.

The data analysis method that is being used was SWOT Matrix and QSPM Matrix (Quantitative Strategic Planning Matrix). The result could be concluded that the SWOT analysis to evaluated of Internal Factor and External Factor by using IFI matrix and EFE matrix and formulated into SPACE matrix that the position of the company was cuurently in an aggressive position. Meanwhile the priority being produced by QSPM Matrix is the biggest priority that is market penetration (first strategy). The result from QSPM Matrix calculation was a strategy with the highest weight as to 6,558.

Data analysis method used was Matrix QSPM (Quantitative Strategic Planning Matrix). Discussion, it can be concluded that the SWOT analysis to evaluate internal and external factors by using matrix EFI and EFE and formulated into the matrix space that the position of the company is currently in an aggressive position. Based on the results of matrix calculations QSPM elected with the highest weight strategy was a first strategy (all in market penetration strategy).
\end{abstract}

Keywords: Quantitative Strategic Planning Matrix (QSPM). 


\section{INTRODUCTION}

Tanggulangin is one of the districts in Sidoarjo that some of the civilians are working in a small leather crafts industry. Varieties of needs in leather materials are produced in this place, starting from slippers, shoes, bags, wallets, suitcases, and jackets, and other things based on leather materials. This leather crafts industry actually started from 1939, and at that time some of the Tanggulangin's bags craftsmen started with bags and suitcases.

The AEC 2015 enforcement had made the government prioritized 9 industry sector to develop in order to fill ASEAN markets, some of them are; agro-based industries (CPO, cocoa, rubbers), fish-processed product industries, TPT industries, shoes and leathers industries, furniture industries, food and beverage industries, and basic metal, iron, and steel industries. The quality product's standard will subscribe to ASEAN's quality standard. Up until now, UMKM products that have chances in ASEAN market, was obstacled by that quality standard.

The problems faced by Small and Medium Industry facing MEA end of 2015 including availability of various industrial raw materials are still many imports, for his own cowhide required of approximately 5,000,000 (five million) pieces, but new domestic production of $2,000,000$ (two million) pieces. The results of the research that has been done in INTAKO, where most SMEs do not have SNI certification. Moreover, for the scale of Southeast Asia is very unfortunate. So concerned shall direct that SME products certified SNI. Another obstacle is not able to meet demand for the number of buyers of products so as to reduce the credibility of SMEs. Lack of facilities to INTAKO, so it would be difficult for buyers who do not know for sure that will impact buyers saturation or less comfortably. This can impact the buyer will be looking for somewhere else besides INTAKO. While the last factor is the quality of service. Lack of uniformity both clothing and the service would be bad images for SMEs. The more services received does not match the buyer hopes the buyer will move on to another place that is welcoming and comfortable.

\section{LITERATURE REVIEW}

Swasta and Sukotjo (1998:82) in Purwoko and Gamal (2016:6) management is the art and knowledge to plan, organize, direct, coordinate and supervise manpower with the addition of tools to achieve the standardized purpose. David (2010:5) in Purwoko, Gamal and Kunhadi (2016), strategic management could be defined as art and knowledge in formulating, implementing, and evaluating functional-traffic decisions that enabled an organization to reach its purpose. Strategic management focused on an effort to integrate management, markets, financial/accounting, product/operation, research and development, and information computer to reach organizational success.

Strategy formulating techniques according to David (2011:76) in Gamal and Purwoko (2016) are integrated to three steps of decision-making framework. The tools presented in this framework applies to every size and kinds of organization and could help, identify, evaluate, and choose strategies. Steps of decision-making framework could be seen in Strategy Formulation Analytical Framework below.

Picture 1: Strategy-Formulation Analytical Framework

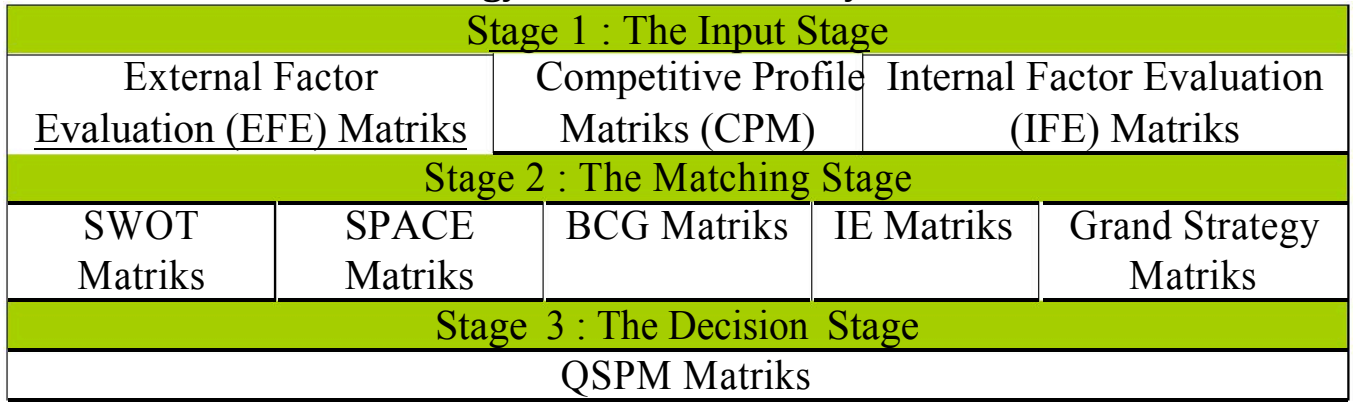

Source: David (2011:177) 
Picture 1 shows the decision making steps framework in formulation strategy. A basic information summary was formed in the first step to formulate a strategy. In input stage there are 3 matrix that is External Factor Evaluation (EFE), Internal Factor Evaluation (IFE) danCompetitive Profile Matriks (CPM). Information from the third matrix becomes the foundation of matrix arrangement and decision-making by determining the corresponding weigh and rating.

Formulating strategy techniques could be integrated into three steps of decision-making framework:

a. Input stage, contains basic information that's needed to formulate a strategy.

b. Matching stage, focused on rational alternative strategy making by noticing primary external and internal factors.

c. Decision stage, involving only one technique, planning matrix, quantitative strategy (QSPM)

\section{SWOT Analysis}

Gitosudarmo (2001:115) SWOT in an approach of strengths, weakness, opportunity and threats. SWOT analysis is a way to analyze competitive position of a company. SWOT analysis is using SWOT matrix to audit or rate an organization within its environment (Kotler, 2009:51). In analytic strategy formulation, SWOT analysis is the first step in Matching Stage. In arranging SWOT matrix, the decision-maker focused on the main problems which therefore helps them to formulate strategy planning.

Matching the primary external and internal factors is the hardest part in developing SWOT matrix and it needs a great assessment.

1. So strategy utilize the company's internal force to attract profits from external chances. Originally, an organization will run WO strategy, ST strategy, or WT strategy in oder to perform SO strategy. If an organization is being faced by a great threat, then a way to avoid it is to concentrate on chances.

2. WO strategy is to fix internal weaknesses in taking profits from external chances. As an example of internal weakness that becomes an obstacle: there may be a high chance of demand in electronics to control the fuel injection time and amount into a machine car (chances), but a spare part producer could not have the needed technology to produce the tool (weakness). One of WO strategy is to acquire this technology through joint venture with other companies who have competency in this aspect. Other alternative is to recruit and train people to have technical capabilities that are needed.

3. ST strategy uses power to avoid or reduce the impact of external threats. This doesn't mean that a strong organization have to always face direct threats in external environment. Example, when Texas Instruments uses an ideal law institution (strength) to have compensation and royalty as much as $700 \$$ from the total of nine Japanese and Korean companies that violates memory chip and semi-conductor patent (threat). This is surely a big threat to every industries possible.

4. WT strategy is a defensive tactic to reduce internal weakness and to avoid external threats. An organization with internal weakness and external threats are in a dangerous position and they may have to work to survive, doing merger, contraction, selfacclaiming broke, or choosing liquidation.

Systematic picture from SWOT Matrix is showed below. A SWOT matrix consists of 9 cells. 4 main cells, 4 strategy cells, and an empty cell (top left). The 4 cell strategy developed after complementing the main cell factor. 
There are 8 steps to make SWOT matrix:

1. Make a company's main external chance list.

2. Make a company's main external threats list.

3. Make a company's main internal strength list.

4. Make a company's main internal weakness list.

5. Match internal strength with external chance, and note the result in SO strategy cell.

6. Match internal weakness with external chance, and note the result in WO strategy cell.

7. Match the internal strength with external threats, and note the result in ST strategy cell.

8. Match the internal weakness with external threats, and note the result in WT strategy cell.

\section{QSPM Matrix}

QSPM Matrix is a matrix used in the decision stage. This QSPM matrix shows the best alternative strategy to be implemented in the company (Zulkarnaen and Sutopo, 2013). In this matrix, the company tests some the best alternative strategy that could be found on the previous stage. The purpose of this QSPM matrix is to determine which the best strategy to be implemented is.

In the decision making stage, the organization needs to arrange the priority list. QSPM is a technique objectively could settle the prioritized alternative strategy. QSPM is used to minimize strategy amount by determining relative attract from every strategies. QSPM has advantages and limitations (Nurfita, 2011) in Gamal and Purwoko (2016:101). Some of QSPM advantages are 1) the strategy series could be observed in orderly, 2) boost the strategy planner to put in relevant internal and external factors into the decision process, 3) developing QSPM minimize the chances that main factors are missed or excessively given weigh, 4) QSPM could be adapted to be used by profit and nonprofit oriented companies so it could be applied to any kinds of organization, 5) the small decisions increase the probability that the end's strategic decision is the best for the organization.

Limitations from QSPM are 1) QSPM always needs intuitive and assumption based assessment, 2) discussion between strategy planner, manager, and coworker in the process of formulating strategy is a constructive thing and fixing the quality of strategy decision, 3) QSPM could only work by precondition information and matching analysis is to be based on. The steps in arranging QSPM are: (Iskandarini, 2004)

1. Making external (chance/threat) factor list and internal factor (strength/weakness) list in the left column of QSPM.

2. Giving weight for every external and internal factor.

3. Analysing the matching matrix from step two by identifying the alternative strategy that is to be implemented.

4. Giving alternative score with the span of:

a. Score $1=$ without attractiveness.

b. Score $2=$ Low attractiveness.

c. Score $3=$ Medium attractiveness.

d. Score $4=$ High attractiveness.

5. Timing the weight and alternative score in each internal and external factor in every strategy.

6. Add up every alternative score.

\section{RESEARCH METHOD}

This research is a continuous research from 2015 that is done in some leather craft industry (mostly bags and suitcases) in Tanggulangin, Sidoarjo. Primary data was obtained from interviews and questionnaire from respondent, observation in field to know the competitive, 
external and internal factors. Secondary data was obtained from literature study and internal bags and suitcases industry.

The criteria will be examined respondents who have knowledge and have experience of the object under study. Respondents were selected to represent a company that is considered to have deep understanding of the competitive conditions and the condition of the company as a whole, such as administrators, entrepreneurs who are members of the Cooperative INTAKO, Department of Industry and Trade Sidoarjo, East Java Province and Kadin East Java Province.

1. Qualitative data, based on descriptive information as related to the submitted problems.

2. Quantitative data, based on numbers as related to the submitted problems.

Based on the source:

1. Primary data was obtained directly from the main source in the companies joint with INTAKO cooperation as to spoken or written from respondent, including interviews, questionnaire, and observation.

2. Secondary data was obtained from some parties in related to this study.

\section{Data accumulation method}

1. Questionnaire, the distribution to stakeholders and interviewees as to weight giving and reviewing internal and external factors.

2. Interview, as to stakeholders and experts who knew the potential from INTAKO's joined companies using guide interview that has been prepared beforehand.

3. Observation, on field to see entrepreneurs in INTAKO's joined companies.

4. Documentation, learning documents that are related to the study.

\section{Analysis data method}

Analysis data method is used to simplify every accumulated data, systematically presented, then process and interpret the meaning of the data. This is to provide answers from the problem of this study. The problem in this study is using SWOT analysis to devise the development strategy with QSPM method.

Descriptive qualitative analysis is an arranging, numbering, classifying, coding, categorizing, and interpreting qualitative and quantitative information without the involvement of numbers.

\section{DISCUSSION}

Respondents in this study are from 53 respondents there are 45 respondents to fulfill the criteria. 8 respondents does not with 6 going out of town and 3 resigned.

\section{SWOT Analysis}

Is one way to analyze the competitive position of a company? SWOT analysis using a technique or a tool called a SWOT Matrix to audit or assess an organization and its environment. In the analytical framework for strategy formulation, SWOT analysis is the first step in Phase Matching. In preparing the SWOT matrix, decision-makers put the focus on the main issues, which then helps them to formulate the strategy. 
Table 3 SWOT Matrix

\begin{tabular}{|c|c|c|}
\hline & Strength (S) & Weakness (W) \\
\hline & $\begin{array}{l}\text { 1. A lot of qualified } \\
\text { manpower }\end{array}$ & $\begin{array}{l}\text { 1. Slow development } \\
\text { products. }\end{array}$ \\
\hline & $\begin{array}{l}\text { 2. Cooperation compiles } \\
\text { leather production. }\end{array}$ & $\begin{array}{l}\text { 2. Less maximal in serving } \\
\text { the costumers. }\end{array}$ \\
\hline & $\begin{array}{llr}\text { 3. } & \text { Raw materials } \\
\text { supplier } & \text { is } & \text { still } \\
\text { fulfilled. } & & \\
\end{array}$ & $\begin{array}{l}\text { 3. Independent promotion is } \\
\text { not maximal. }\end{array}$ \\
\hline & $\begin{array}{l}\text { 4. Sopshiticated } \\
\text { production machine. }\end{array}$ & $\begin{array}{l}\text { 4. Products aren't } \\
\text { certificated yet. }\end{array}$ \\
\hline & $\begin{array}{l}\text { 5. Getting promotion } \\
\text { support from leather } \\
\text { industry exhibiton. }\end{array}$ & 5. Low quality product \\
\hline & $\begin{array}{l}\text { 6. Products with } \\
\text { affordable price. }\end{array}$ & \\
\hline Opportunities (O) & S-O Strategy & W-O Strategy \\
\hline $\begin{array}{l}\text { 1. Government's policy in } \\
\begin{array}{l}\text { enhancing } \\
\text { sector for AEC. }\end{array}\end{array}$ & $\begin{array}{ll}\begin{array}{l}\text { Educated } \\
\text { enough to }\end{array} & \begin{array}{l}\text { manpower is } \\
\text { compete }(\mathrm{S} 1,\end{array} \\
\mathrm{O} 2) & \end{array}$ & $\begin{array}{l}\text { Promotion } \\
\text { enhanced }(\mathrm{W} 3, \mathrm{O} 2, \mathrm{O} 3)\end{array}$ \\
\hline $\begin{array}{l}\text { 2. Leather crafts industry is } \\
\text { still considered as the } \\
\text { best industry. }\end{array}$ & $\begin{array}{l}\text { Doing } \\
\text { promotion }(\mathrm{S} 5, \mathrm{O} 2, \mathrm{O} 3)\end{array}$ & $\begin{array}{l}\text { Product development needs } \\
\text { to be enhanced (W1, O1) }\end{array}$ \\
\hline $\begin{array}{l}\text { 3. Vacation enhancement to } \\
\text { Tanggulangin }\end{array}$ & $\begin{array}{l}\text { Product with competitive } \\
\text { prices }(\mathrm{S} 6, \mathrm{O} 6)\end{array}$ & $\begin{array}{l}\text { Product needs to be } \\
\text { certificated }(\mathrm{W} 4, \mathrm{O} 4)\end{array}$ \\
\hline $\begin{array}{l}\text { 4. Raw materials } \\
\text { product buying } \\
\text { reachable }\end{array}$ & & \\
\hline $\begin{array}{l}\text { 5. Leather crafts products } \\
\text { are having potential as } \\
\text { market leader }\end{array}$ & & \\
\hline Threats (T) & S-T Strategy & W-T Strategy \\
\hline $\begin{array}{l}\text { 1. Products from ASEAN } \\
\text { would add the competiton }\end{array}$ & $\begin{array}{l}\text { Manpower } \\
\text { training }(\mathrm{S} 1, \mathrm{~T} 5)\end{array}$ & $\begin{array}{l}\text { Product development should } \\
\text { be intensified (W1, T4) }\end{array}$ \\
\hline $\begin{array}{lrr}\begin{array}{l}\text { 2. Products } \\
\text { from } \\
\text { with } \\
\text { affordable prices }\end{array} & \begin{array}{r}\text { other } \\
\text { much }\end{array} \\
\end{array}$ & $\begin{array}{l}\text { Affordable and qualified } \\
\text { products }(\mathrm{S} 6, \mathrm{~T} 2)\end{array}$ & $\begin{array}{l}\text { All products needs to be SNI } \\
\text { certificated (W4, W5, T1, } \\
\text { T4) }\end{array}$ \\
\hline $\begin{array}{ll}\begin{array}{l}\text { 3. Society chooses } \\
\text { products because }\end{array} & \text { of the } \\
\text { quality. } & \\
\end{array}$ & $\begin{array}{l}\text { Increasing } \begin{array}{l}\text { promotion } \\
\text { with social media (W3, } \\
\text { T1) }\end{array} \\
\end{array}$ & \\
\hline $\begin{array}{l}\text { 4. Same kinds of products } \\
\text { from ASEAN }\end{array}$ & & \\
\hline $\begin{array}{l}\text { 5. Enhancement of foreign } \\
\text { manpower's wage. }\end{array}$ & & \\
\hline
\end{tabular}

\section{QSPM Matrix Analysis}

After developing a number of strategic alternatives, the company should be able to evaluate and then choose the best strategy palingcocok with the company's internal conditions and external environment. There are 6 steps to make QSPM matrix (David, 2002):

1. Arranging the same list as swot

2. Giving weight 
3. The same as ifi and efe

4. Arranging alternative strategy that is to be evaluated

5. Attractiveness score

6. Counting total alternative score. Adding weight with as value on each internal/external factors in every strategy

7. Counting the total of as

Table 3. Total Alternative Score (TAS)

\begin{tabular}{|c|c|c|c|c|c|c|c|c|}
\hline \multirow[t]{2}{*}{ No } & \multirow{2}{*}{$\frac{\text { Factor }}{\text { Strength }}$} & \multirow[b]{2}{*}{ Weight } & \multicolumn{2}{|c|}{ Strategy 1} & \multicolumn{2}{|c|}{ Strategy 2} & \multicolumn{2}{|c|}{ Strategy 3} \\
\hline & & & AS & TAS & $\overline{\mathrm{AS}}$ & TAS & AS & TAS \\
\hline 1 & $\begin{array}{l}\text { Leather crafts industry in Sidoarjo have } \\
\text { qualified labor. }\end{array}$ & 0,111 & 4 & 0,444 & 4 & 0,444 & 3 & 0,333 \\
\hline 2 & $\begin{array}{l}\text { Having cooperation to compile leather crafts } \\
\text { production }\end{array}$ & 0,118 & 2 & 0,236 & 3 & 0,354 & 3 & 0,354 \\
\hline 3 & Raw materials from supplier is still reachable & 0,119 & 3 & 0,357 & 3 & 0,357 & 4 & 0,476 \\
\hline 4 & $\begin{array}{l}\text { Having sophisticated production machine } \\
\text { from merchant ministry }\end{array}$ & 0,112 & 3 & 0,336 & $\overline{4}$ & 0,448 & 4 & 0,448 \\
\hline 5 & $\begin{array}{l}\text { Getting promotion support from } \\
\text { Of place and leather crafts product exhibition }\end{array}$ & 0,116 & 3 & 0,348 & $\overline{3}$ & 0,348 & 3 & 0,348 \\
\hline 6 & Marketed products have affordable price & 0,108 & 3 & 0,324 & 4 & 0,432 & 3 & 0,324 \\
\hline & Weakness & & & & & & & \\
\hline 1 & $\begin{array}{l}\text { Acceleration in developing products is still } \\
\text { slow }\end{array}$ & 0,048 & 3 & 0,144 & 3 & 0,144 & 4 & 0,192 \\
\hline 2 & Less maximal service to costumer & 0,058 & 4 & 0,232 & 3 & 0,174 & 3 & 0,174 \\
\hline 3 & $\begin{array}{l}\text { Promotion independently without the } \\
\text { assistance of relevant authorities is still less } \\
\text { than the maximum }\end{array}$ & 0,054 & 4 & 0,216 & $\overline{4}$ & 0,216 & 4 & 0,216 \\
\hline 4 & $\begin{array}{l}\text { Handicraft products waas not yet ISO } \\
\text { certified. }\end{array}$ & 0,048 & 4 & 0,192 & $\overline{3}$ & 0,144 & 4 & 0,192 \\
\hline 5 & Low product quality. & 0,053 & 4 & 0,212 & 4 & 0,212 & 4 & 0,212 \\
\hline 6 & Limitations of venture capital & 0,056 & 3 & 0,168 & 3 & 0,168 & 3 & 0,168 \\
\hline & Opportunities & & & & & & & \\
\hline 1 & $\begin{array}{l}\text { Leather industry has a huge potential market } \\
\text { in which the population of the largest in the } \\
\text { ASEAN Indonesia. }\end{array}$ & 0,119 & 3 & 0,357 & 3 & 0,357 & 3 & 0,357 \\
\hline 2 & $\begin{array}{l}\text { Leather products has the potential to become } \\
\text { the market leader especially in East Java } \\
\text { during the Asean Economic Community } \\
\text { (AEC) menginggat the support of the } \\
\text { Provincial Government promotion. East Java } \\
\text { regency. Sidoarjo. }\end{array}$ & 0,124 & 4 & 0,496 & 3 & 0,372 & 3 & 0,372 \\
\hline 3 & $\begin{array}{l}\text { Government policies in terms of increasing } \\
\text { the industrial sector to face the Asean } \\
\text { Economic Community (AEC). }\end{array}$ & 0,127 & 3 & 0,381 & 2 & 0,254 & 2 & 0,254 \\
\hline 4 & $\begin{array}{l}\text { Leather industry in waas until today is still } \\
\text { regarded as the best craft center in East Java. }\end{array}$ & 0,126 & 3 & 0,378 & 2 & 0,252 & $\overline{3}$ & 0,378 \\
\hline
\end{tabular}




\begin{tabular}{|c|c|c|c|c|c|c|c|c|}
\hline 5 & $\begin{array}{l}\text { With the ASEAN free trade or AEC, is } \\
\text { affecting an increase in tourist visits to } \\
\text { Tanggulangin }\end{array}$ & 0,127 & 3 & 0,381 & 3 & 0,381 & 2 & 0,254 \\
\hline \multirow[t]{2}{*}{6} & $\begin{array}{l}\text { Purchase of raw materials and the addition of } \\
\text { production equipment from abroad can be } \\
\text { purchased easily. }\end{array}$ & 0,116 & 4 & 0,464 & 3 & 0,348 & 3 & 0,348 \\
\hline & Threats & & & & & & & \\
\hline 1 & $\begin{array}{l}\text { The products of ASEAN will flood the market } \\
\text { in Indonesia entry into force of the Asean } \\
\text { Economic Community. }\end{array}$ & 0,049 & 3 & 0,147 & 3 & 0,147 & 3 & 0,147 \\
\hline 2 & $\begin{array}{l}\text { Products from other countries cheaper prices } \\
\text { with a wide variety and quality of products }\end{array}$ & 0,058 & 4 & 0,232 & 3 & 0,174 & 3 & 0,174 \\
\hline 3 & \multicolumn{2}{|l|}{$\begin{array}{l}\text { Indonesian residents often prefer to buy } 0,054 \\
\text { foreign products as the life style and the } \\
\text { assumption that foreign products of better } \\
\text { quality. }\end{array}$} & 3 & 0,162 & 4 & 0,216 & 3 & 0,162 \\
\hline 4 & $\begin{array}{l}\text { The emergence of similar products originating } \\
\text { from ASEAN countries. }\end{array}$ & 0,049 & 3 & 0,147 & 3 & 0,147 & 4 & 0,196 \\
\hline 5 & $\begin{array}{l}\text { The increase in labor costs is likely caused by } \\
\text { a number of skilled workers seeking work in } \\
\text { Indonesia. }\end{array}$ & 0,051 & 4 & 0,204 & 3 & 0,153 & 3 & 0,153 \\
\hline \multicolumn{2}{|r|}{ Total } & & & 6,558 & & 6,242 & & 6,232 \\
\hline
\end{tabular}

QSPM above calculation results based on the input from internal matrix external weights, as well as the strategy alaternatif matching stage. So, after collecting data then can be some of the results for comparison with the strategy of internal factors and external factors, among others, the strategy of 6.558, 6.242 and strategies of two of the three strategies of 6.232. Based on the results of matrix calculations QSPM chosen strategy with the strategy of the highest weight of 6.558. (Market penetration strategy). Market penetration, which is trying to increase market share for existing products on the market through a more vigorous marketing efforts.

Market penetration strategy to be successful, then the craft industry entrepreneurs Tanggulangain Sidoarjo regency leather industry should be supported by, among others:

1. Support the Government in the development of infrastructure businesses boost productivity and encourage the growth of the business, will have no significance for the community, if their products can not be marketed or, if they can be sold, but at a very low price. Therefore, it is an important component in efforts to increase the quality and quantity of products Tanggulangain leather industry is the production and marketing infrastructure. Through their marketing infrastructure from the production site to the market, will reduce the marketing chain and ultimately increase revenues Tanggulangain leather industry.

2. Network development handicraft industry leather industry Tanggulangain Sidoarjo. Through the development of business jariangan be expanded with a wide range of network patterns, for example in the form of subcontracting network. The pattern of such networks already formed but in realiatasnya still not optimal. The pattern of business networks through subcontracting can be used as an alternative for the existence of the craft industry leather industry Tanggulangain Sidoarjo. But 
unfortunately many small industries that just do not have a network of subcontracting and linkages with large companies that are vulnerable existence. So have the opportunity to be a product that has a competitive advantage and can compete in the global market.

3. Banking provides capital credit facilities. Through the ease of obtaining loans for entrepreneurs Tanggulangain leather industry, is expected to be capital untuyk product development. Thus the bank is expected to no longer just hunting for companies that have been established, but also a pioneer to develop the potential of the economy by growing the leather industry employers Tanggulangain Sidoarjo district through support of the ease of obtaining capital for business development.

4. Leather industry Tanggulangain Sidoarjo Regency wile employees is an important factor for any business as well as in the small business sector. The success of small-scale industries that can compete with similar products and are able to penetrate global markets or face of imported products in the domestic market is determined by the ability of actors in the small industry to develop products so that their business can still exist. Makia development of small and medium enterprises, governments need to improve training for the leather industry Tanggulangain Sidoarjo district both in terms of entrepreneurship, administration and knowledge and skills in business development. Improving the quality of human resources is done through various ways such as education and training, seminars and workshops, internships in the workplace and business cooperation.

\section{CONCLUSION}

Based on the results of data processing and analysis in the previous chapter, it can be concluded as follows:

a. SWOT analysis to evaluate internal and external factors by using matrix EFI and EFE and formulated into the matrix space that position the company at this time are in a position Aggressive

b. Priority produced by QSPM matrix is the greatest priority is the market penetration (the strategy). The results of matrix calculations QSPM chosen strategy with the highest weight of 6.558 .

\section{RECOMMENDATION}

Suggestions can be submitted in this study are:

1. To develop its business Tanggulangain leather industry employers Sidoarjo district needs to be improved internally which includes improving services, increasing the number of production, ISO certified products, accelerate product development, and increase promotion.

2. Employers Tanggulangain Sidoarjo regency leather industry need to start to do the promotion by using flyers, brochures, leaflets, pamphlets, or other promotional media, so that more potential customers know of the existence Tanggulangain leather industry. 


\section{Bibliography}

David, 2011, Strategic Management, 10 ${ }^{\text {th }}$ edition, Salemba Empat, Jakarta. 2009, Strategic Management, Salemba Empat, Jakarta.

Gamal, A and Purwoko, B., 2016. Grand Strategy dan Quantitative Strategic Planning Matrix, Insan Global, Mojokerto.

Gitosudarmo, H. I., 2001. Strategic Management,Yogyakarta: PT BPFE.

Iskandarini, 2004, Problem solving and Decision Making Analysis, Agriculture Faculty Sumatera Utara University, Medan.

Kotler, Philip. 2009. Marketing Management $1^{\text {st }}$ issue, $11^{\text {th }}$ ed . Jakarta: PT. Indeks.

Purwoko, B., Gamal, A., and Kunhadi, D., 2016, The choosing of leather industry development in Tanggulangin strategy using internal external matrix and quantitative strategic planning matrix approach, Journal International Conference on Entepreneurship $3^{\text {rd }}$ University Ciputra, Surabaya.

Purwoko, B., dan Gamal, A., 2016. Marketing Research with Regression Tool (Company Marketing Management Study Case), Insan Global. Mojokerto.

Rangkuty, Freddy, 1997. SWOT Analysis Business Case Operation Technique, $2^{\text {nd }}$ edition, PT. Gramedia Pustaka, Jakarta.

Zulkarnaen, H. O., and Sutopo., 2013. Marketing Strategy Towards Micro Company and Middle Company of Snack (UKM Snack Barokah Research Study in Solo), Diponegoro Journal of Management 2nd (3):1-13. 